\title{
The Process of Decision-Making of Foreign Direct Investment in Special Economic Areas
}

\author{
José G. Vargas-Hernández, (M.B.A.; Ph.D.) \\ Vania Y. López-Mayorga \\ University Center for Economic and Managerial Sciences. University of Guadalajara \\ Periférico Norte 799 Edif. G201-7, Núcleo universitario Los Belenes, Zapopan, Jalisco, \\ Mexico.
}

\begin{abstract}
The objective of this paper is to analyze the decision making process on foreign direct investment (FDI) as well as the location strategies used as the main objective which is the achievement of greater profits via cost reduction. Part of the assumption that the Special Economic Zones (ZEE) recently decreed (2016) offer tax incentives that allow them to reduce costs to foreign companies, encouraging them to establish them in these areas. A comparative analysis of the EEZs with the state of Jalisco as a reference, since this is characterized as an industrialized and attractive state for the arrival of FDI. The method used was a comparative analysis of the descriptive scope of variables such as population by age group, level of education and the Global Indicator of Economic Activity (IGAE), as well as the IED. Finally, the main conclusion is that the strength of these states under the EEZ regime is the Economically Active Population (EAP). However, the decree that establishes these special zones in Mexico must be accompanied by policies that strengthen the educational and social and security conditions in these States.
\end{abstract}

KEYWORDS: Special Economic Zones, decision Making, location strategies.

\begin{abstract}
Summary
The objective of this work is to analyze the decision making process of Foreign Direct Investment (FDI) as well as the location strategies used, which as main objective is the achievement of greater profits via cost reduction. Part of the assumption that the Special Economic Zones (EEZs) recently decreed (2016) offer tax incentives that allow them to reduce costs to foreign companies, encouraging them to establish them in these areas. A comparative analysis of the EEZs with the state of Jalisco is made as a reference, since this is characterized as an industrialized and attractive state for the arrival of FDI. The method used was a comparative analysis of the descriptive scope of variables such as population by age group, level of education and the Global Indicator of Economic Activity (IGAE), as well as the IED. Finally, the main conclusion is that the strength of these States under the EEZ regime is the Economically Active Population (EAP). However, the decree that establishes these special zones in Mexico must be accompanied by policies that strengthen the educational and security conditions in these States.
\end{abstract}

Keywords: Special Economic Zones, decision making, location strategies. 


\section{Introduction}

The Special Economic Zones are part of the regional development policies that the national executive has proposed in 2016. In April 2018, the last economic zones are decreed to make a total of 7 benefiting the States of Chiapas, Guerrero, Michoacán, Oaxaca, Veracruz, Tabasco and Yucatán. The main objective of this policy is to attract foreign investment to promote and improve the living conditions of the population of these Southern States. These states with homogeneous social characteristics, high degrees of poverty, significant unemployment rates, as well as conditions of insecurity have prevailed in recent years. These conditions determine the direction of the investment through the location of new production plants. While companies focus on maximizing the profits of their firms, the state has to promote economic growth.

Thus, one of the benefits granted by the Special Economic Zones is the reduction of costs through tax subsidies, as part of the benefits established by the Federal Government to promote the arrival of new companies and preserve domestic investment in these regions. On the side of companies, their managers, among other activities, have to make investment decisions and where to direct their new investments. The possibilities of choice can be limited in analyzing factors such as the population, the educational levels of the population, the activities in which the region or States specialize. In this analysis, the characteristics of the states of Chiapas, Guerrero, Michoacán, Veracruz and Oaxaca are described, and compared with the state of Jalisco, as a state characterized by well-defined industrial zones.

In the first part the concept and definition of the Special Economic Zones are analyzed, as a measure of regional economic growth, the emergence of this type of zones worldwide and the adoption of this measure in Mexico. In the second part, it analyzes the main theories that incorporate technology processes and competitive dynamics and how these variables influence the process of decision making by firms. In the third part, an empirical review of the decision-making process of locating strategies of foreign capital companies is presented. In the section on the research method, population and specialization characteristics of the economic activities of the States are specified. Finally, the main results of the analysis are analyzed and some conclusions and scopes of analysis are presented.

\section{Background of the problem}

\section{A. The Special Economic Zones (EEZ): Measure to promote regional economic growth}

Since the birth of capitalism as an economic system originated as a result of the Industrial Revolution, this system was adopted by numerous countries around the world, including Great Britain, the United States and Germany (Olivares, 2014). In Latin America, countries such as Mexico, Brazil and Colombia, to name a few examples. However, given the characteristics of each region, this system had more or less impact and was reflected in the same way in the economic growth of the countries. Other countries, in contrast, adopted the socialist system as an alternative doctrine of growth. The representative example of pure socialism was in the extinct Soviet Union and now the People's Republic of China.

It is particular to mention the latter country for the significant economic growth it has had in recent years, as a result of the adoption of free market measures, an essential feature of capitalism, by some of its regions. Among the measures adopted is the establishment of Special Economic Zones (SEZs) whose main objective is to contribute to the economic growth of lagging regions (high poverty rates, low level of infrastructure, declining levels of industrialization, etc.). This type of measure has been adopted by Mexico almost 60 years after the emergence of the first EEZ (Shannon free zone in Ireland in 1959).

In Mexico, on June 1, 2016, the Federal Law on Special Economic Zones was issued, with the objective of promoting "sustainable economic growth". Currently these areas are: "Puerto Lázaro Cárdenas, which includes neighboring municipalities of Michoacán and Guerrero; that of the Corridor of the Isthmus of Tehuantepec, which will include the poles of Coatzacoalcos, Veracruz, and Salina Cruz, Oaxaca; and that of Puerto Chiapas, in Chiapas "(SE, 2016). In figure 1 is shown the main EEZs.

http://dx.doi.org/10.19085/journal.sijmd050601 


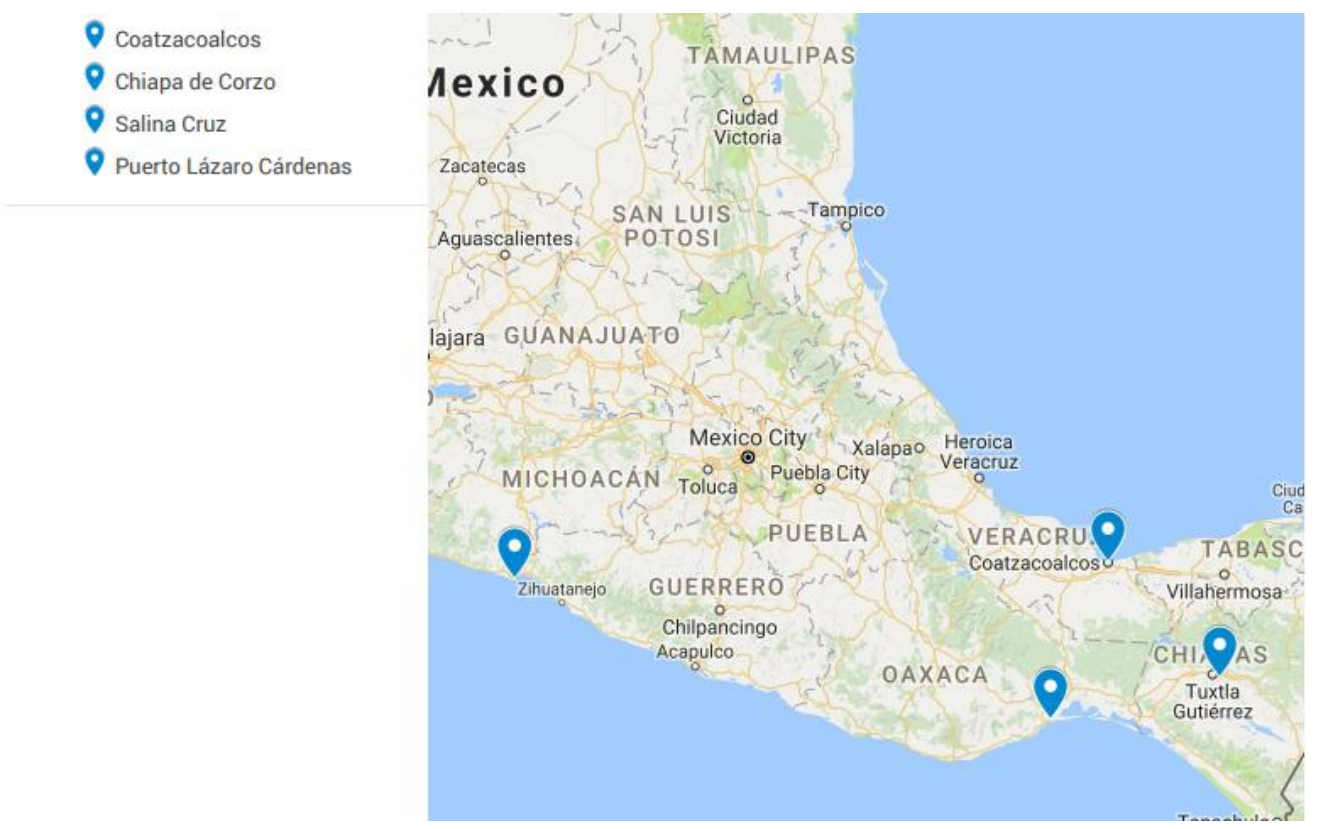

Figure 1. Location of EEZs in Mexico. On April 6, 2018, the Coordination Agreement for the Establishment and Development of the EEZ of Progreso, Yucatán is signed (for the purposes of this analysis, this zone is excluded).

Source: Google maps

Through these zones it is intended to provide investors in the form of individuals or corporations:

"Fiscal, customs and financial benefits, as well as administrative facilities and competitive infrastructure, among other special conditions, under the terms of this Law. The benefits and incentives that are granted shall promote the generation of permanent employment, industrial promotion, growth of the productivity of work, and productive investments that promote the economic development of the Zone and its Area of Influence "(LFZEE, 2016, p.1).

Without being specialists in regional development or strategic management, it can be deduced that the success of any economic or business policy will depend on the socioeconomic and political conditions of each country, state or region. From this simple, but at the same time complex proposition, it is questioned about the decision-making process that companies (of foreign capital) have to invest under this ZEE regime or invest in an area with a different regime.

In the organizational analysis, Nelson and Winter (1982) reconcile the economic analysis and the decision-making process of the companies introducing the importance of technological progress and the dynamics of the competitive process as key variables that determine the decisions taken by the companies.

To combine topics of Regional Development through EEZ as a growth policy and the decision making of companies as part of its Strategic Management is imperative. With the aim of offering on which their decisions are based the companies with foreign capital with the intention of investing and determining the weight of the zones under this specific scheme, technological progress and the dynamics of the competitive process are taken as primary variables in this decision-making process. 


\section{Theoretical-conceptual review: Technological progress and competitive dynamics within the decision-making process}

\section{A. Technological progress and competitive dynamics}

The interest of economic growth in order to solve market failures (the emergence of noncompetitive markets, the existence of externalities, the deficient distribution of income and problems of economic imbalances: unemployment, poverty, among others) has resulted in the proposal of new models (Olivares, 2014, p.37). One of these models is the one developed by Robert Solow in which he introduces technological progress as a determinant of growth.

On the other hand, Joseph A. Schumpeter established as a premise of his model that "the greatest driving force that interrupts the steady state of the economy is technological progress or innovation" (Olivares, 2015, p.40), that is, progress caused by technological advance will cause changes in the current state of any economy. Olivares, (2014) analyzes the Schumpeter model and identifies that entrepreneurs are the fundamental element that allows the analysis of economic growth. By relating innovation to technological progress and that this relationship conditions the success of private companies. From the Schumpeterian approach, private companies adopt two fundamental positions, while some strive to be leaders, others are limited to imitate, even adopt existing technology, these characteristics implicit in each type of company will determine its competitive dynamics (Nelson \& Winter, 1982).

Private companies, given the dynamics they adopt to achieve a level of competitiveness, will seek to compete not at a price level, but through the creation of new products that allow them to conquer new areas outside their local market. This business growth will provide the conditions for the private company to analyze new markets and the degree of success they could have when choosing any of them.

Most of the companies that make up the Mexican economy are subject to the imitation of technologies from companies in central countries such as the United States, Germany, Japan, France and the United Kingdom (G5). As Myro (2010) emphasizes: "in economies with a low level of development, [...], technical progress should be more based on imitation than on one's own technological effort" (Myro, 2010, p.3), Therefore, in cases such as Mexico, policies on the attraction of private investment must focus on attracting companies through tax incentives so that they can articulate their technologies with local companies and that the latter can adopt them.

\section{B. The decision-making process of companies to establish themselves in an EE}

The decision-making process on the part of those responsible for the companies, must arise from a thought of analysis, since making a bad decision would compromise the financial assets. The decision-making process starts at the first moment with the signals that the same market launches. Within the local market, increases in the demand for goods and services as a result of an increase in individual incomes could make entrepreneurs think of setting up a new branch. The same happens in international markets, that is to say, the economic conditions of countries different from the local one that present significant economic growth makes it attractive for investment. However, it must be analyzed not only the economic growth of the destination country, but many other variables that may influence the success or failure of the new company.

The EEZs are implemented to attract Foreign Direct Investment (FDI) through the establishment of foreign companies that seek to expand their new plants as a result of the growth they have in time " $t$ ". These zones seek to provide the necessary conditions, offering incentives for prosecutors, infrastructure by the local government and labor, natural resources intrinsic to the area of establishment.FDI is defined as "one whose purpose is to create a lasting bond for long-term economic and business purposes, by a foreign investor in the host country" (SE, 2018). This turns out to be the main measure to analyze the main destinations that companies have within our country.

The companies, therefore, have to analyze the best conditions offered by the destination market, as

well as evaluate the conditions offered by the SEZs and compare them with other zones that are not under this regime. The central problem for decision makers within organizations would be centralized in 
analyzing the target market, in this case the special zone, since, on the one hand, it offers savings in costs via taxes, cheap labor, however, these spaces are characterized by social problems, such as poverty and insecurity.

In the other part of the analysis that those responsible for these decisions have to carry out, it is to analyze the establishment of a new company in an area that is not under this regime. An industrial state like Jalisco in which the Metropolitan Zone of Guadalajara (ZMG), comprised by the municipalities of San Pedro Tlaquepaque, Tonalá, Zapopan, Tlajomulco de Zúñiga, El Salto, Ixtlahuacán de los Membrillos and Guadalajara that meets characteristics developed as a hand of specialized work, infrastructure more or less consolidated but in which the fiscal regime does not offer the same benefits and natural resources as in a special area.

It is therefore necessary to establish the mechanism that leads the decision-making process. This concept was defined by Herbert Simon as "a planned and cooperative effort, in which each participant has a recognized role to fulfill and some obligations or tasks to be performed. They are assigned to these obligations to achieve the objective of the organization rather than to satisfy individual preferences, although often both effects coincide"(Cabeza, Muñoz, \& Vivero, 2004, page 2-3 quoted from Navia, 1999).

The objective then of the process of making a decision in a company refers to the growth of the organization and not to satisfy the interests of the individual responsible for the decision. It can be analyzed this decision assuming localization models of companies, such as the Transportation Model, an analytical tool used to find the lowest possible costs to distribution problems from the central plant to different destinations (Heizer \& Render, 2008). This tool for localization is supported by other methods such as the Rule of the northwest corner, the Intuitive Method and the Stepping-Stone Method, however, all these methods converge to the central issue that is the strategic decision making of the companies, product of substantial growth.

The need for expansion begins to have more weight within organizations and within the decisionmaking process the uncertainty and risk of the investment have to be examined. Gathering as much information as possible that mitigates the effects of these variables, will base the success or failure of the decision made by the entrepreneurs or managers of the company. On the other hand, Cabeza et al. (2004), compile the main models for decision making, listing them below:

1) Rational model

2) Model of economic rationality

3) Bounded rationality model

4) Organizational behavior model

5) Model of garbage cans

6) Model of Kepner-Tregoe

7) Model of Mintzberg, Raisinghani and Thèorêt

8) Model of political rationality

9) Incrementalism model

10) Vroom-Yettom model for making individual or group decisions.

These models can be effective to the extent that they adapt to the circumstances presented by the company or organization. However, these authors (Cabeza, Muñoz, \& Vivero, 2004), point out other factors that may influence decision making: the importance, the time-cost relationship, uncertainty, complexity, the circumstances in which the decision is made, including the personality traits of who is going to make the decision. In this way, some features can be judged subjective, however, they play an important role in this process.

In the model Mintzberg, Raisinghanni and Thèorêt from the decision-making process can be studied from three perspectives: research done by cognitive psychologists from the point of view of game theory, the research carried out by psychologists as practical tests to groups focused and finally from the perspective of the political scientists of how the decision making in the field is made.Although these 
models are useful for making decisions, they are based on solving internal problems of companies, hiring personnel, purchasing fixed capital, and so on.

The game theory approach, within strategic management by senior managers, turns out to be an appropriate tool in which possible scenarios, players and payments that would be received when taking one or another decision are considered. Game theory gathers the necessary elements for strategic decision making by managers, in scenarios of risk and uncertainty, satisfying the requirements that expanding companies need and thus be able to decide the destination region, it is convenient to establish a new plant. This always evaluating the two possibilities posed by an EEZ or another that is not under this regime.

The tools for decision making by FDI have been varied and viewed from different perspectives, each evaluating different conditions. Up to this moment we have analyzed theories and models that are useful accompanied by mathematical analyzes, even cognitive ones by the heads of the expanding companies.

The theory of location exposed at the end of the XIX century and the beginning of the XX as one of the most relevant contributions for the Industrial Economy, offers the sufficient bases to approach our problem of study, since through the theory and the models of location, the managers and entrepreneurs of the company will have arguments that can place them in scenarios to achieve the economic growth of their firm.

\section{Review of the empirical literature.}

\section{A. Perspectives for the definition of strategic decisions for the location of a company}

The theory of localization has Von Tünen, Marx Weber, Walter Christaller and Gerrit Losch and later Marshall, Henderson and Hottelling to its main exponents (Hernández, 2009, p.11). For microeconomic analysis, that is, how economic agents make decisions, the assessment and incorporation of space is fundamental in this type of studies. Hernández, (2009), identifies that it is the transportation cost that will determine the location.On the other hand, already in the empirical analysis, Carbajal, (2004) mentions two aspects used for the location of a plant or new company. The first is based on macro-location, and refers to "the selection of the appropriate region or area, evaluating the regions that preliminarily present certain attractions suitable for the industry in question" and the micro-location as the one in which "the selection specifies of the site or terrain found in the region that has been evaluated as the most convenient "(Carbajal, 2004, p.31).

This author states factors and sub factors that can influence the strategic decision making for the location of a new company, clarifies that they are not listed in order of importance and that in turn are not limiting in the analysis. In this list the author includes:

i. Workforce
a) Cost
b) Availability
c) Stability
d) Productivity

ii. Markets
a) From customers

b) Of raw materials

iii. Energetics

a) Electric power

b) Fuels

iv. Communications and transport 
a) Transportation

b) Communications

v. Water

vi Characteristics of the place

a) Climate and topography

b) Urban development

c) Industrial development

d) Commercial development

vii. Environmental control

viii. Costs of life

ix. Fiscal and financial aspects (Carbajal, 2004, p.22)

At an international level, the problem of location has been addressed, as it has been said previously, with the aim of reducing transport costs. However, in the analysis other variables have been incorporated, such as the specialization of the workforce, the availability of human resources, as well as the role of institutions. Giving a brief review of the Strategic Management of Organizations, Vargas, Guerra, Bojórquez \& Bojórquez (2005), recapitulate about considerations based on industry, resources and institutions as strategies that firms can use to succeed within the internationalization process.

In the considerations based on the industry, companies are considered as entities whose main objective is to maximize their benefits, so that horizontal alliances are formed, in which competitors are grouped. Another type of strategy is vertical alliances upwards which consist of forming alliances with suppliers, downward vertical alliances are formed when firms join with buyers and distributors.

The considerations sustained on the resources based on the VRIO framework, try to explain its strategy of alliances and networks. In value, it is intended that alliances between companies create value (for example the reduction of the cost of selling their products). In rarity, there are two dimensions, the rarity of the capacities and the rarity of the partner. In the first, it is related to the capacity of relationship or collaboration among firms, that is, how companies can successfully manage their internal relationships, in the rarity of the partner, this is defined by Peng $(2012$, p.195) as "The difficulty of locating some partners with certain desirable attributes".

The imitation factor focuses on the level of the firm and the level of the alliance, which establish that the resources and capabilities of the firms are limited and also to the imitations such as the trust and understanding that members can achieve within alliances and obtain success. And finally, we have the organization, also focused at the signature level and at the alliance or network level.

The considerations based on the institutions are centered on formal and informal institutions. On the side of formal institutions that are supported by regular entities such as the government and its regulations and laws, in which companies must pay attention to regulations that have to do with. For example, antitrust and the requirements of the way entry. On the other hand, there are informal institutions backed by cognitive and formative pillars.

Paying special attention to these variants that are proposed together with the application of the location model for FDI with the possibility of entering the Mexican market through its establishment in the EEZs, represents a partially complete framework that can help those responsible to make these kinds of decisions.

\section{Research method}

\section{A. Analysis of decision making of Foreign Direct Investment}


Investment decisions of foreign companies can be measured through FDI. Therefore, it is proposed to analyze the socioeconomic conditions of the EEZs and to make a comparative analysis with the ZMG that allows to identify the characteristics that may impact the decision making process of location of foreign capital investment. The scope of this analysis is descriptive, variables such as population by age group, educational level, investment and economic activities through the Global Indicator of Economic Activity (IGAE), are presented by the degree of importance for each state of the so-called EEZ.

The EEZ includes the States of Michoacán, Guerrero, Veracruz, Oaxaca and Chiapas (Puerto Progreso in Yucatán is under this special regime. However, it is excluded from this analysis since the signature of the agreement was made after those of these States). The comparative analysis is represented with the state of Jalisco, as it is an area with significant economic growth in recent years.

The following figure1 shows the evolution of the FDI that it has had from the year 2000 to 2017, the average of the investment of the States that have an EEZ has been taken.

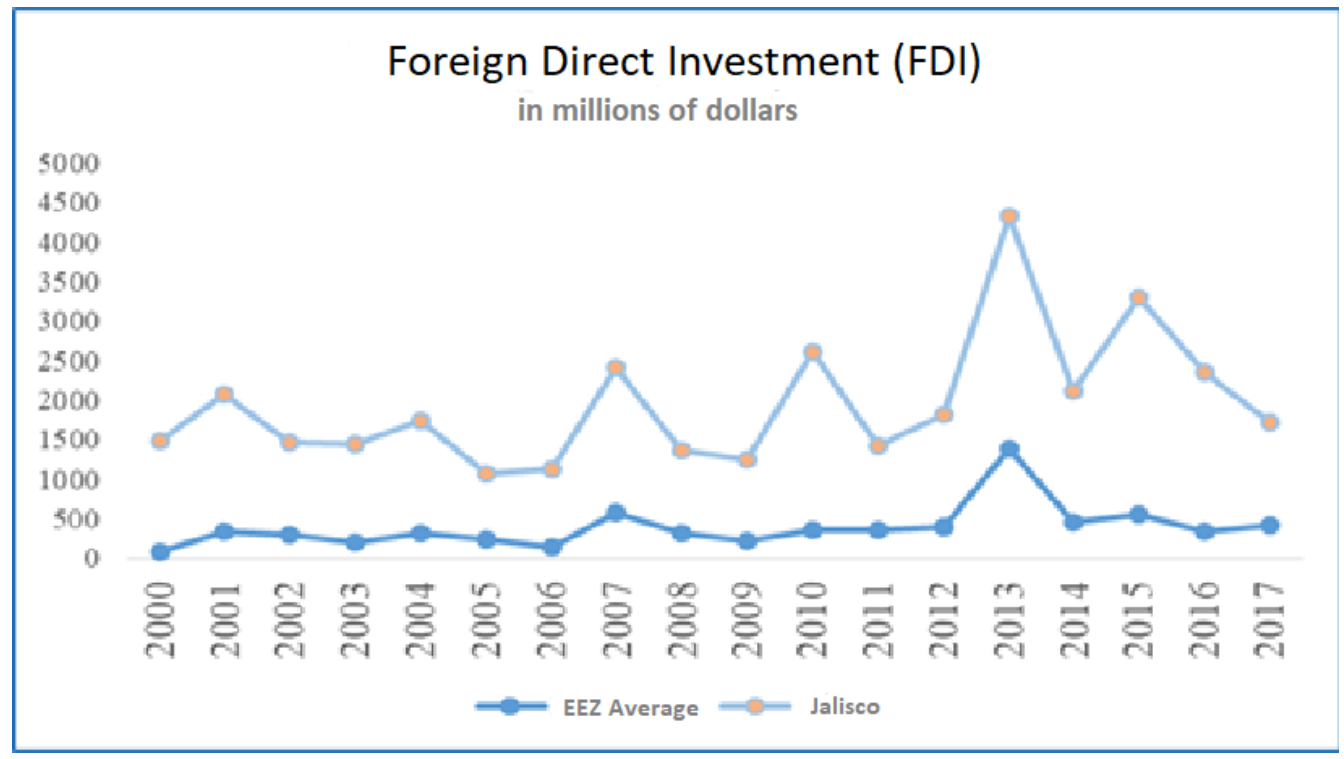

Figure 1. Foreign Direct Investment in the EEZ

Source: Prepared by the authors with data from INEGI, 2018

The differences are significant. On the one hand, there are high levels of investment in the region of the state of Jalisco, while the average of the EEZ is considerably low for the entire period, except for the year 2013, which identifies a rebound in this type of investments. Another important aspect to contrast is the population aged 15 to 59 years, the age range considered by INEGI as the Economically Active Population (EAP) and the educational level (INEGI, 2018), since these are variables that explain human capital as a factor that FDI needs for its operations (See figures 2 and 3 ). 


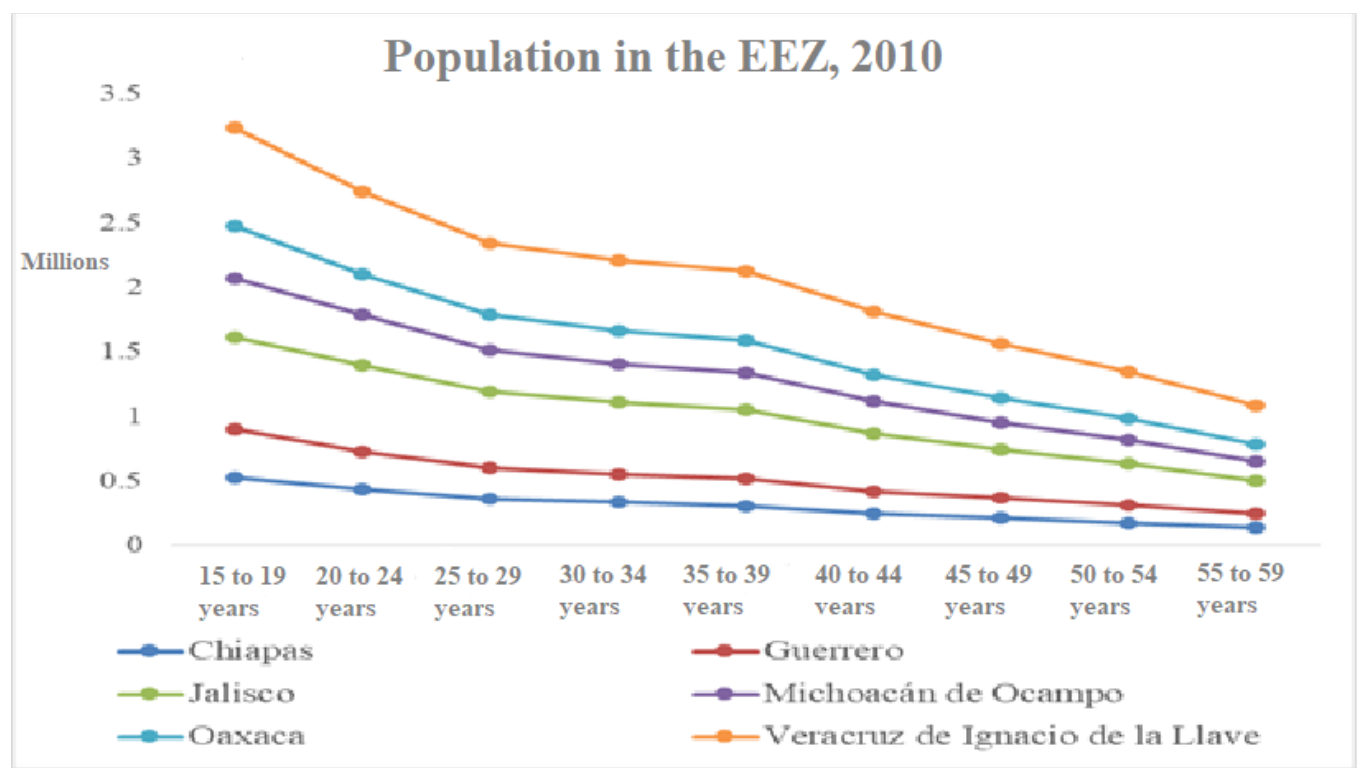

Figure 2. Population in the EEZ, 2010

Source: Own elaboration with data from Population and Housing Census 2010.

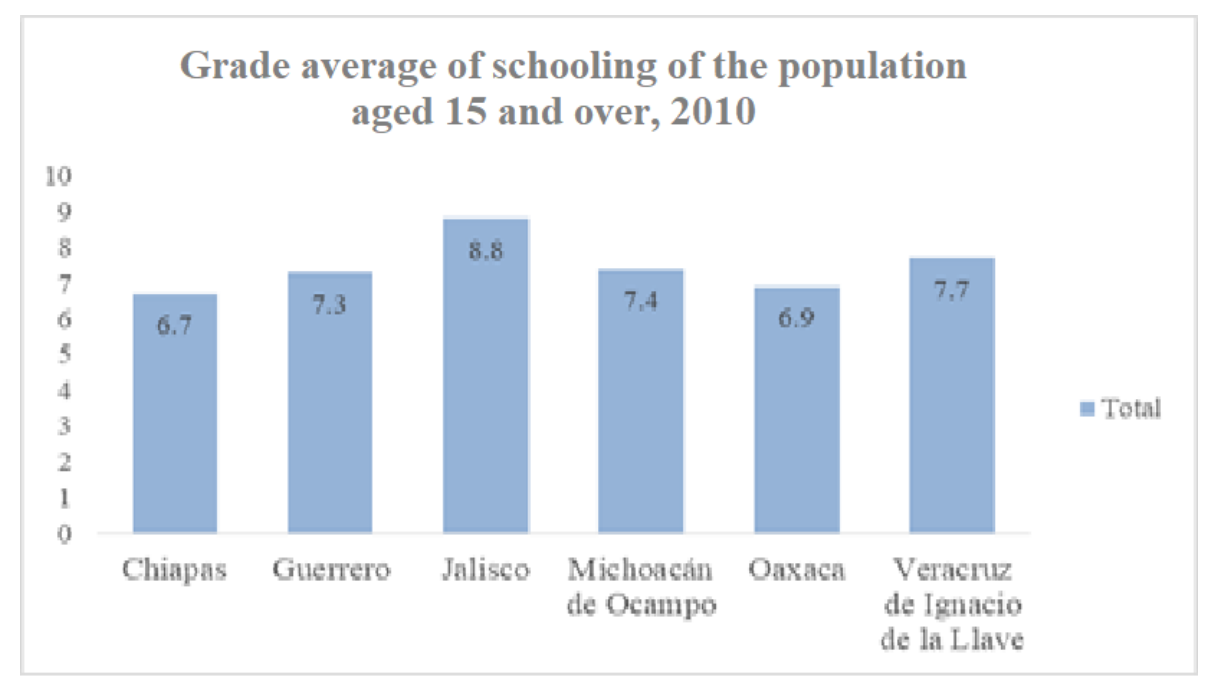

Figure 3. Grade average of schooling

Source: Own elaboration with data from Population and Housing Census 2010.

Regarding the specialization of the economic sectors, the IGAE defines Primary Activities such as agriculture and the breeding and exploitation of animals (livestock), Secondary Activities include mining, generation, transmission and distribution of electricity, water supply and gas by pipelines to the final consumer, construction and manufacturing industries, and finally the tertiary Activities that includes wholesale and retail trade, transport, mail and storage, information in mass media, financial and insurance services, services real estate and rental of personal and intangible assets, professional, scientific and technical services, business support services and waste and waste management, and remediation services, educational services, health and social assistance services, recreational services, cultural and sports, and other recreational services, temporal accommodation services to the preparation of food and beverages, other services except government activities and legislative, governmental, and justice activities, and international and extraterritorial organizations (INEGI, 2013). 
For the elaboration of this total indicator of the IGAE, the average was taken from the first quarter of 2010 until the fourth quarter of 2017. In the annexes section, the descriptive statistics are presented to reference the deviations of each type of economic activity.

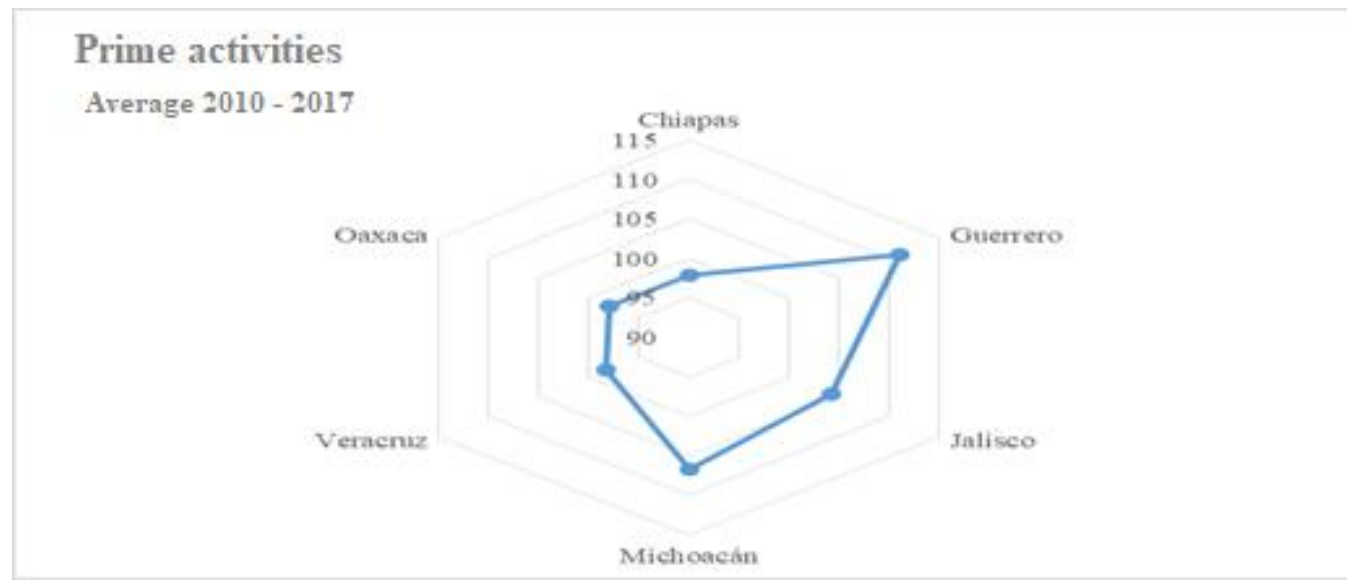

Figure 4. Prime activities

Source: Own elaboration with data from INEGI, 2013

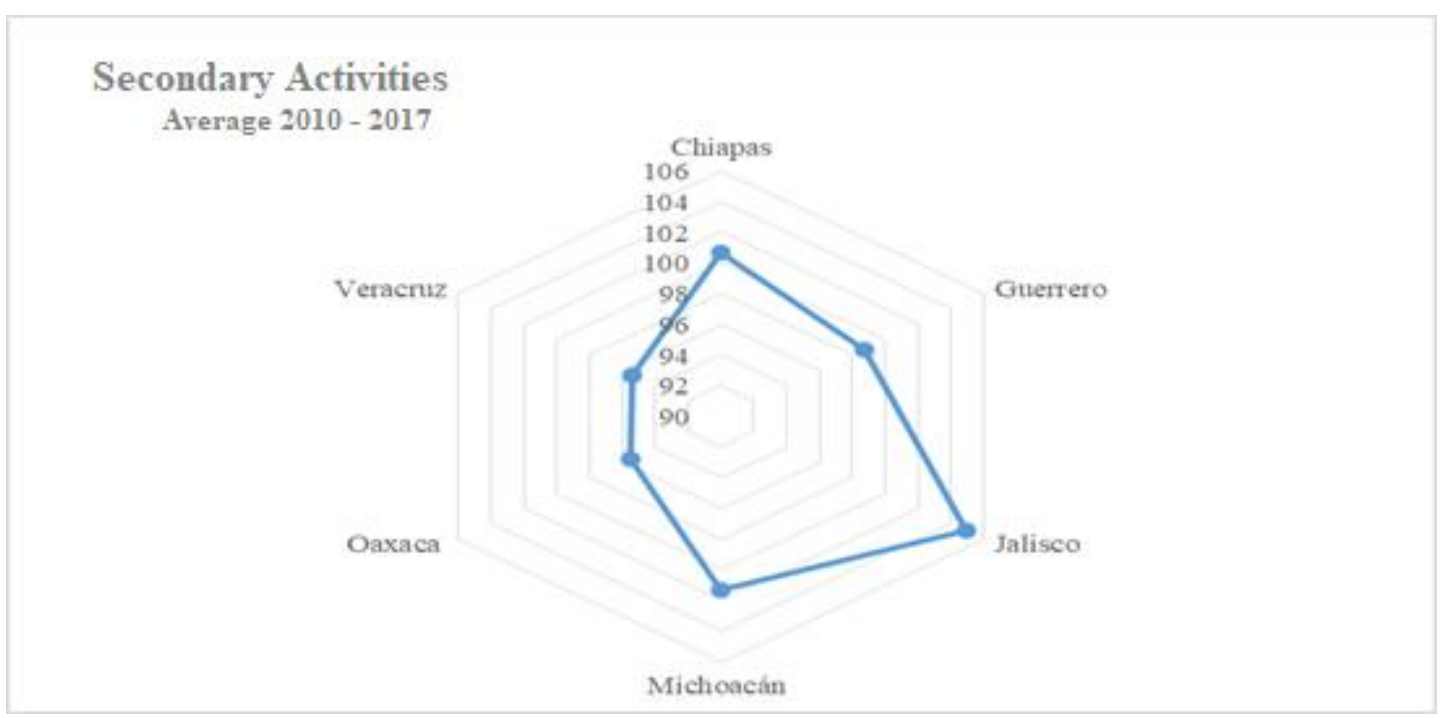

Figure 5. Secondary Activities

Source: Own elaboration with data from INEGI, 2013 


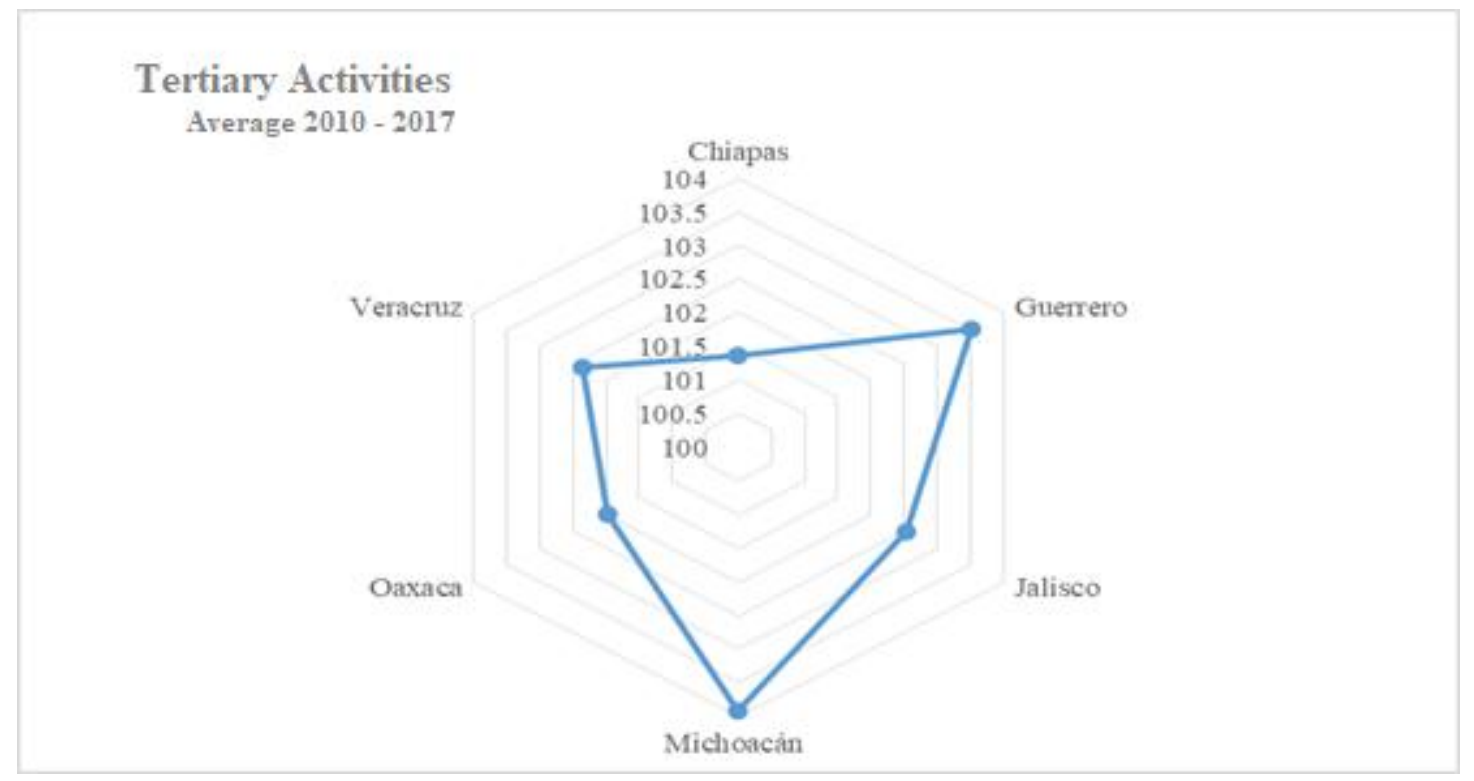

Figure 6. Tertiary Activities

Source: Own elaboration with data from INEGI, 2013

\section{Analysis of Results}

In the descriptive analysis that was carried out about the EEZs (Chiapas, Guerrero, Michoacán de Ocampo, Oaxaca and Veracruz) comparing these Zones with the population conditions of the State of Jalisco, we find that the States of Veracruz, Oaxaca and Michoacán, are significantly more populated in the age groups in the ranges of 15 to 59 years of age defined as PEA, this condition gives an advantage to the aforementioned States by the demographic bonus that these States still possess. It should be noted that the population as a labor force is relevant for FDI that seeks new locations to establish itself.

On the other hand, the Average Grade of Schooling gives advantage to the state of Jalisco ( 8.8 years) since it is above the States in which the EEZ is decreed, followed by Veracruz, Michoacán and Guerrero, while the States of Chiapas and Oaxaca have a lag since they are below 7 years of average schooling of the population. This educational factor is also relevant for FDI, since having specialized labor will also represent a determining factor for its establishment.

The specialization of the States measured in this analysis through the IGAE, shows that the States of Guerrero and Michoacán are intensive in primary activities such as agriculture and livestock, Jalisco is intensive in Secondary Activities defined these activities as mining, generation, transmission and distribution of electrical energy, supply of water and gas through pipelines to the final consumer, construction and manufacturing industries. This is important for companies that seek that their place of establishment has the necessary infrastructure conditions for the operation of activities in goods and / or services that they produce, the State of Michoacán and Chiapas are the States that follow in terms of the intensity of the Secondary Activities. Finally, we have the Tertiary Activities, in which the state of Michoacán, followed by Guerrero, are those that present the most specialization in these activities (See tables 1,2 and 3 ). 
Table 1. Descriptive statistics of primary activities

\begin{tabular}{lllllll}
\hline & Chiapas & Guerrero & Jalisco & Michoacán & Veracruz & Oaxaca \\
\hline Media & & & & & & \\
Median & 97.92 & 110.99 & 104.19 & 106.66 & 98.21 & 97.96 \\
Standard deviation & 100.06 & 108.13 & 101.75 & 102.91 & 98.45 & 101.82 \\
Sample variance & 18.04 & 16.09 & 15.32 & 24.31 & 20.80 & 21.18 \\
Rank & 325.48 & 258.90 & 234.72 & 591.19 & 432.68 & 448.49 \\
Minimum & 65.32 & 61.21 & 51.55 & 108.74 & 70.33 & 65.98 \\
Maximum & 66.50 & 86.55 & 81.78 & 71.59 & 66.00 & 65.27 \\
\hline
\end{tabular}

Table 2. Descriptive statistics of secondary activities

\begin{tabular}{lllllll}
\hline & Chiapas & Guerrero & Jalisco & Michoacán & Oaxaca & Veracruz. \\
\hline Media & & & & & & \\
Median & 100.71 & 98.69 & 104.96 & 101.37 & 95.52 & 95.37 \\
Standard deviation & 103.30 & 98.34 & 103.76 & 100.47 & 95.71 & 95.47 \\
Sample variance & 13.03 & 7.46 & 11.18 & 6.45 & 8.23 & 4.82 \\
Rank & 169.70 & 55.59 & 124.95 & 41.65 & 67.80 & 23.23 \\
Minimum & 49.32 & 29.10 & 34.61 & 30.57 & 33.63 & 18.09 \\
Maximum & 75.26 & 88.95 & 88.92 & 93.35 & 80.27 & 84.88 \\
\hline
\end{tabular}

Table 3. Descriptive statistics of tertiary activities

\begin{tabular}{lllllll}
\hline & Chiapas & Guerrero & Jalisco & Michoacán & Oaxaca & Veracruz \\
\hline & & & & & & \\
Media & 101.36 & 103.52 & 102.53 & 103.93 & 101.97 & 102.36 \\
Median & 102.48 & 102.42 & 101.78 & 102.90 & 101.68 & 101.96 \\
Standard deviation & 7.01 & 5.70 & 9.27 & 9.39 & 4.95 & 6.50 \\
Sample variance & 49.19 & 32.50 & 85.89 & 88.25 & 24.54 & 42.25 \\
Rank & 24.69 & 21.99 & 36.65 & 31.94 & 18.02 & 23.67 \\
Minimum & 87.49 & 92.23 & 86.88 & 89.15 & 91.85 & 89.01 \\
Maximum & 112.18 & 114.22 & 123.53 & 121.09 & 109.87 & 112.68 \\
\hline
\end{tabular}

These characteristics can be seen clearly reflected in the behavior of FDI in the average of the EEZ and contrasting it with the FDI carried out in the state of Jalisco (Figure 1), it is clearly shown that the socioeconomic conditions are decisive for the decision making of foreign investment since this entails looking for the optimal conditions for the establishment of new companies.

\section{Conclusions and Recommendations}

The EEZs represent the opportunity for the States under this new tax exemption regime that seek to promote, through the tax subsidy, attract FDI with the new establishment of companies that strengthen the potential of labor that these States have.

Carrying out this comparative analysis of EEZs and the state of Jalisco as a reference delimited by strategic factors such as population by age group, schooling level and IGAE are variables that determine and are related to FDI, since theories such as of the location whose transport model seeks to reduce costs by 
means of transporting resources to production plants, thus represent alternatives that companies have for the process of their decision making.

These States in which they were decreed as regions or special zones have the social imperative of improving economic conditions, which guarantee the improvement of the living situation of their population. It was found in this analysis that the greatest strength is its population of working age (PEA from 15 to 59 years), these resources have to be exploited, however, the law decree of the EEZ must be accompanied by other policies that provide for the improvement and strengthening of the educational conditions of the population, so that it can be competitive against the PEA of States with better economic indicators as the case of the State of Jalisco.

The decision-making process on the part of the FDI will be sent to increase the profits of the organizations and in this search will permeate the need to evaluate the costs of establishing in one or another location, in a special zone or in an industrialized state. It is therefore presented that the assessment of the conditions of the States will not only reduce costs by means of the taxes they have to cover to start operations, but also the factors presented in this study, but also including others such as security provided by these States. Including the security variable is a limitation of this work, but it is considered important for future analysis.

In this way, the government of each of the States, as well as the Federal Executive still have a great task and is to guarantee the necessary conditions for the operation of new companies that have the possibility of choosing an EEZ as a location.

\section{References}

[1]. Cabeza, L., Muñoz, A. E., \& Vivero, S. M. (2004). Aproximación al proceso de toma de decisiones en la empresa barranquillera. Revista Pensamiento y Gestión, núm. 17, 1-38.

[2]. Carbajal, A. M. (2004). Planeación Estratégica de la planta. Nuevo León, México: Universidad Autónoma de Nuevo León.

[3]. Heizer, J., \& Render, B. (2008). Dirección de la producción y de operaciones. Decisiones tácticas. Madrid: Person.

[4]. Hernández, G. I. (2009). Liberalización Comercial y Localización Industrial en México(Tesis doctoral). Universitat de Barcelona, Barcelona, España.

[5]. INEGI (2018). Instituto Nacional de Estadística y Geografía. Obtenido de http://www.inegi.org.mx/est/contenidos/espanol/sistemas/cem07/texcom/glosario/glosario.htm

[6]. INEGI (2018). Instituto Nacional de Estadística y Geografía. Censo de Población y Vivienda 2010. Obtenido en http://www.beta.inegi.org.mx/app/tabulados/pxweb/inicio.html?rxid=d518b312-a32e-4d23-a8dd08a64c187a6c\&db=Poblacion \&px=poblacion_1

[7]. INEGI (2013). Instituto Nacional de Estadística y Geografía. Sistemas de Cuentas Nacionales de México: Fuentes y Metodologías. Año base 2013. Indicador Global de la Actividad Económica (IGAE). Recuperado de http://www.inegi.org.mx/est/contenidos/proyectos/cn/igae/doc/SCNM_Metodo_IGAE_B2013.PDF

[8]. Secretaria de Gobernación (2016). Ley Federal de Zonas Económicas Especiales (LFZEE). Diario Oficial de la Federación, 1-29. Recuperado de http://dof.gob.mx/nota_detalle.php?codigo=5439557\&fecha=01/06/2016

[9]. Myro, R. (2010). Crecimiento económico e innovación: Un breve apunte hacia la evidencia empírica. RevistaGalega de Economía,vol. 19, 1-15.

[10].Nelson , R., \& Winter, S. (1982). An Evolutionary Theory of Economic Change. Cambridge Massachusetts: Harvard University Press.

[11]. Olivares, E. M. (2014). Sistemas económicos y modelos de economía moderna. Bogotá: Universidad Autónoma de Colombia.

[12].SE. (28 de Enero de 2016). Secretaría de Economía. Obtenido de https://www.gob.mx/se/articulos/las-zonaseconomicas-especiales-de-mexico

[13].SE. (8 de Abril de 2018). Obtenido de https://www.gob.mx/se/articulos/que-es-la-inversion-extranjera-directa

[14].Peng, M. W. (2012). Global Strategy. Cincinnati: Thomson South-Western.

[15]. Vargas Hernández J. G. y Guillen Mondragón I. J. (2005). Los procesos de transformación estratégica en relación con la evolución de las organizaciones, Estudios Gerenciales, No 94, Enero-marzo del 2005. Universidad ICESI. 65-80. ISSN: 01206648. 